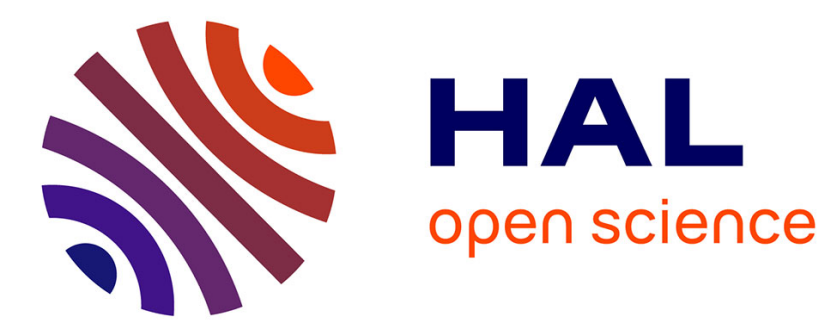

\title{
The male mate search: an optimal foraging issue?
}

Philippe Louâpre, Xavier Fauvergue, Joan van Baaren, Véronique Martel

\section{To cite this version:}

Philippe Louâpre, Xavier Fauvergue, Joan van Baaren, Véronique Martel. The male mate search: an optimal foraging issue?. Current Opinion in Insect Science, 2015, 9, pp.91-95. 10.1016/j.cois.2015.02.012 . hal-01205879

\section{HAL Id: hal-01205879 \\ https://hal.science/hal-01205879}

Submitted on 17 Nov 2015

HAL is a multi-disciplinary open access archive for the deposit and dissemination of scientific research documents, whether they are published or not. The documents may come from teaching and research institutions in France or abroad, or from public or private research centers.
L'archive ouverte pluridisciplinaire HAL, est destinée au dépôt et à la diffusion de documents scientifiques de niveau recherche, publiés ou non, émanant des établissements d'enseignement et de recherche français ou étrangers, des laboratoires publics ou privés. 


\section{The male mate search: An optimal foraging issue?}

By Philippe Louâpre ${ }^{1 *}$, Xavier Fauvergue ${ }^{2}$, Joan van Baaren ${ }^{3}$, Véronique Martel $^{4}$

1. University of Burgundy, UMR CNRS 6282 Biogeosciences -6 bd Gabriel, 21000 Dijon, France.philippe.louapre@u-bourgogne.fr

2. Institut Sophia Agrobiotech, UMR INRA-CNRS-UNS 1355 - 400 route des Chappes, BP 167, 06903 Sophia Antipolis Cedex, France. xavier.fauvergue@sophia.inra.fr

3. University of Rennes 1, UMR CNRS 6553 Ecobio - Avenue du Général Leclerc, 35042 Rennes Cedex, France. joan.van-baaren@univ-rennes1.fr

4. Natural Resources Canada, Canadian Forest Service, Laurentian Forestry Centre 1055 rue du P.E.P.S., P.O. Box 10380, Stn. Ste-Foy, Québec (Québec), Canada. veronique.martel@rncan.gc.ca

* Corresponding author 


\begin{abstract}
Male insects must find and mate females to have some descendants; male fitness therefore depends on the number of females they inseminate. Males are for this reason expected to optimize the behaviors related to mate location, orientation and copulation. Although optimization of the reproductive behavior of males has long been neglected in the literature, recent studies suggest a renewed interest for this idea. Here we discuss the parallel between male mate-finding and mating strategies in insects and Optimal Foraging Theory, a class of models which formalize the behavior of organisms seeking and exploiting resources, generally food. We highlight the different facets of male mating systems allowing such a parallel, and claim for a unifying approach of foraging behavior. Finally, we discuss novel research perspective emerging from the application of Optimal Foraging Theory to male reproductive behavior.
\end{abstract}

\title{
Keywords
}

Mating, fitness, optimization, foraging behavior, males, insect 


\section{Introduction}

Since A. J. Bateman's pioneer study on Drosophila melanogaster [1], it is expected that male behavior evolves to maximize the number of females they mate as a result of their relatively cheap and numerous gametes. Females, because they invest more energy in gametes and the subsequent production of offspring, are thus considered as the choosy sex: females gain less from multiple copulations than males, but being approached by many competing males, they are expected to select the fittest and/or most compatible mate [2]. In contrast to this common belief, the difference between male and female utility functions appears less dramatic [3-7]: the evolution of reproductive strategies in males must be nuanced by trade-offs between the direct benefits of mating with the maximum number of females and the costs associated with mating. Producing sperm, searching and accessing females after courtship, fighting with rivals, and ensuring paternity when females are polyandrous are well-known examples of reproductive costs in insect males [8-14]. Given these costs, the ultimate causes of male reproductive behavior should be much better understood through an application of the paradigm of optimization.

In this manuscript, we draw a parallel between male mate-finding and mating strategies and Optimal Foraging Theory (OFT), a keystone class of models from behavioral ecology that formalize the behavioral adaptation of organisms seeking and exploiting resource (generally food). We derive the main assumptions and predictions from OFT models to males foraging for females. In the past, optimization analyses of insect male 
behavior has been implemented to predict sperm allocation [18] and time allocation to courtship, female-guarding [15-17], or foraging on female patches [19,20]. Given the renewed interest for such approaches, it is time to discuss the relevance of applying ratemaximization models to male reproductive strategy and extending the classic prey and patch with such a perspective.

\section{Male foraging behavior with regard to Optimal Foraging Theory}

Two basic questions form the core of classic OFT: which food item should a forager select, and when should a forager leave a food patch [21]. Several general assumptions that do not depend upon the specific question underlie the theory (Table 1). Foragers gain energy by consuming food items, but finding and consuming each food item takes a significant amount of time $[22,23]$ so that foragers are selected to maximize the average rate of energy intake during lifetime [21]. Average rate of energy intake is expected to correlate positively with fitness; in the jargon of OFT, average rate of energy intake is a "currency" for fitness. These assumptions can easily be translated in the context of male reproduction (Table 1). The number of females mated is likely correlated with male fitness, probably even more than food items are correlated with forager fitness [1,24] so that males maximizing their lifetime mating rate should be advantaged under natural selection. Searching and mating females are time-consuming activities that males cannot achieve simultaneously. For instance, the time to handle females (i.e. courtship, copulation and post-mating guarding), to recover after mating, to produce another nuptial gift or even to produce more sperm are 
many examples of time constraints that should shape the utility function that insect males should maximize [12,16,25]. Moreover, males have a reproductive period limited by their capacity to transfer sperm, such period being temporary (synspermatogenic males) or definitive (prospermatogenic males) as it has recently been pointed out in Hymenoptera [14]. The currency of OFT can thus be adapted to males foraging for females and translate into an average rate at which males find and mate females over a limited period of time.

\section{Which type of females to consume? Male strategy in the light of the prey model}

The prey model analyses the choice of resource items a forager should include in its diet in order to maximize its long-term average rate of energy intake. It assumes that foragers have to select food items that differ in profitability (measured by the balance between costs and benefits of selecting items of a given type). The decision to select a food item of a given type depends on the rate at which each item is encountered in the environment. How can these assumptions be derived when females are the items that males exploit (Table 1)?

\subsection{Females of varying profitability}

For a male, the profitability of a female results from the balance between benefits and costs. The profitability of a female results directly from her ability to produce progeny bearing the male's genes. It can be influenced by individual characteristics such as age, body size and metabolic reserves or mating status [2,26-30], which modify the female's fecundity. The benefit males gain from mating varies according to these female attributes, just like the gain 
of foragers varies with food quality. Moreover, mating females induce many costs for males; these costs include mate searching and locomotion, mate accession, fights with competitors, insemination, nuptial gifts, etc. These costs could appear as key factors in the evolution of male preferences for a given type of females [11,16,24,31,32], possibly underestimated in the available literature.

\subsection{Choosy males?}

Should the classic prey model apply to male reproduction, the main prediction would be that the decision to mate a female relies on a threshold depending on the rate at which each type of females is encountered (Table1). There is no evidence in the literature that males select females according to their encounter rate with females of different types. However, choosy males have been found in many insects taxa [24,33-40]. In particular, the strength of male preference toward females of a given phenotype depends on the variance in female quality and the costs of mating for males: preference increases when males suffer a higher cost of mating [41,42]. Hence, male behavior is consistent with predictions from the prey model, in the sense that their choice depends on trade-offs between costs and benefits of mating a given type of females. Moreover, the prey model predicts that time to access and exploit mobile resource influences the optimal choice [43]. Females are similarly mobile so that males should adapt their decision to their encounter rate with females.

Obviously, the prey model does not perfectly fit the foraging behavior of males, because it does not consider (i) the response of the resource towards the forager, and (ii) the behavior of the forager after expressing its choice. (i) In the prey model, even if preys or 
hosts can respond by escaping or defending themselves, choices are made solely by the forager. Mate choice differs [33], as mating results from the attraction of one sex by the other, with the latter having a control over being "consumed" or not. Hence, the outcome of male choice depends not only on its own choice (true choice) but also on the response of the female (apparent choice) [34,44]. (ii) Copulation duration, guarding duration, sperm quantity and/or quality transferred to the females are many examples suggesting that insect males adapt their investment in females according to their profitability [45-50]. As a consequence, applying the prey model to males foraging for females should not only consider the outcome of the matching between a male and a given type of female, but also the complete sequence of mating, including all behaviors subsequent to copulation.

\section{Leaving a hot spot? Male strategy in the light of the patch model}

Food items are generally aggregated in the environment. Unexploited patches vary in quality and patch exploitation result in patch depletion, which also contribute the variability among patches. As in the prey model, time is a central constraint: traveling from patch to patch and exploiting a patch takes a significant amount of time acting as a primary constraint in the evolution of patch use behavior. The patch model assumes that foragers visit patches sequentially and allocate time to each patch according to its quality: the higher the patch quality relative to the environment-wide expected intake rate, the longer the patch residence time (Marginal Value Theorem, MVT) [23]. The optimal decision to leave a patch (i.e., the patch residence time maximizing the long-term rate of energy gain) depends 
on a threshold intake rate below which the forager should decide to stop exploitation. Can these assumptions and predictions be adapted in the context of males foraging for females (Table1)?

\subsection{Sequential visits on female patches.}

In insects, females may aggregate into discrete patches for a number of reasons. Females can aggregate (i) if they exploit a resource such as food or hosts that is itself patchily distributed [51], (ii) if social interactions among females or agonistic behaviors of males for females lead them to aggregate [52], or (iii) if females develop and emerge simultaneously in a restricted area [19]. Moreover, depletion may occur in female patches because after mating, females loose a large amount of their profitability for males. The rate of patch depletion results from patch exploitation by males: the number of profitable females decreases with the number of matings [15]. Female patches are nonetheless highly unstable in species where females are highly mobile, which imposes additional costs to the forager, as shown for some parasitoid insects [43]. It is therefore crucial to consider the distribution of females in space and time to understand the forces shaping the behavior of males foraging for patchily distributed females.

\subsection{Males adapt their patch residence time.}

Do males estimate the quality of female patches and adapt their foraging behavior accordingly? OFT applied to male dung flies show that males adapt copulation time to the quality of females $[15,53]$, and recent research suggests that time allocation is also relevant in the context of males exploiting patches of females. Like foragers on food or host patches, 
male insects exploiting female patches use local information such as sexual pheromones or contacts with virgin females [19,54], and adapt patch departure based on proximate mechanism $[55,56]$. Male decision to leave a female patch relies on information on female density and the number of mated females, which yield patch residence times consistent with predictions from the MVT [57]. Hence male insects can optimize their residence time on female patches.

\section{Implication for future research}

We argue that applying OFT to male reproduction is relevant, but also point out on peculiarities of underlying behaviors that limit a simple parallel between OFT and male reproduction (Table 1). Male reproductive behavior does not fit a simple maximization criterion. It should be better viewed as a complex optimization problem with specific currencies. The parallel between OFT and male reproductive behavior is worth the debate, but the paucity of strong demonstration to date could make the debate sterile. Rather, this idea should yield testable predictions guiding and inspiring future research.

\section{Suboptimal rate-maximizing strategy?}

The main prediction resulting from the theory detailed above is that the reproductive behavior of insect males results in a lower mating rate than the higher rate potentially achieved in the environment. The reason is that male fitness is underpinned by other currencies than a mere mating rate, because males gain to reject females depending on their 
quality or availability. We thus suggest that optimal male mating rate should be seen, as for females [2], as reaction norms rather than a constant and evolutionary fixed optimum. Males should consequently adapt their mating frequency to experienced environmental conditions such as mating costs, female quality and spatial / temporal distribution.

\section{Mating patterns and population dynamic depend, in part, on the male choice}

Although mate choice is generally attributed to females, male mate choice by males has been recognized for its role in mating patterns and its consequent influence on sexual selection [58]. The optimality perspective developed here may serve to understand the consequences of male choice on population dynamic. For instance, males of some insect species continue to mate after being sperm-depleted [40,59]. Although such a behavior can appear as an evolutionary conundrum, it was hypothesized that such a behavior increases the fitness of sperm-depleted males by having a direct influence on the offspring sex-ratio [40]. From our perspective, we predict that sperm-depleted males exhibit a specific foraging behavior reflecting competition with conspecific males rather than a direct transmission of gametes. Further researches are thus needed to better understand how fertilization potential determines male foraging strategy.

\section{Males exhibit proximate mechanisms of foraging.}

If males face an optimal foraging issue, we can predict that they will display proximate mechanisms common to optimal foraging in other contexts. These mechanisms have been thoroughly described in the case of parasitoids foraging for hosts [56,60,61], and recent studies show interesting analogies between female exploiting host patches and male 
exploiting female patches $[19,20]$. For instance, male tendency to leave a female patch depends on the total number of females as well as the number and status of the females encountered, just like the female tendency to leave a host patch depends on the total number of hosts and the number and status of the hosts encountered. Research on the behavioral ecology of parasitoids is fruitful and dynamic [61]. We therefore expect a rising interest for the mechanistic and cognitive underpinnings of male mate choice and patch exploitation.

\section{Conclusion}

In this paper, we proposed that OFT could be applied to better understand some facets of male reproduction such as male mate choice and male behavior when females are patchily distributed. The underlying idea is that male reproductive strategy is certainly not the result of a simple maximization of the number of matings. Rather, male reproduction is better understood as a complex optimization problem, and OFT is a relevant paradigm to formalize questions and interpret observations. We thus detailed the specific situations where OFT could be applied to male foraging for females (Table 1). We argue that females can be envisaged as resources of varying quality for males, with possible aggregation and depletion, so that classic optimal foraging models such as the prey and patch models are likely relevant for analyzing male reproductive behavior. Reasoning male foraging behavior in terms of optimality nonetheless depends on idiosyncrasies of insect species, including the mating system or the social system. We thus point out that any optimal 
behavior is understandable only if all the variables underlying the decision process are considered. For instance, the preference for a given type of female may depend on the female intrinsic quality but also on environment-wide characteristics such as the predictability and distribution of other females. To date, little is known about the way male insects perceive and use information in order to optimize their foraging strategies. We thus hope behavioral ecologists will be interested in the idea that male insects may exhibit optimal foraging behaviors. 
References

* References of special interest

1. Bateman AJ: Intra-sexual selection in Drosophila. Heredity (Edinb). 1948, 2:349368.

2. Arnqvist G, Nilsson T: The evolution of polyandry: multiple mating and female fitness in insects. Anim Behav 2000, 60:145-164.

3. Collet JM, Dean RF, Worley K, Richardson DS, Pizzari T: The measure and significance of Bateman's principles. Proc. R. Soc. B 2014, 281.

*4. Pizzari T, Wedell N: The polyandry revolution. Phil. Trans. R. Soc. B 2013, 368.

*5. Parker G, Birkhead T: Polyandry: the history of a revolution. Proc. R. Soc. B 2013, 368.

6. Fritzsche K, Arnqvis G: Homage to Bateman: sex roles predict sex differences in sexual selection. Evolution 2013, 67:1926-36.

7. Jones AG, Ratterman NL: Mate choice and sexual selection: What have we learned since Darwin?. PNAS 2009, 106:10001-10008.

8. Papadopoulos NT, Liedo P, Müller H-G, Wang J-L, Molleman F, Carey JR: Cost of reproduction in male medflies: The primacy of sexual courting in extreme longevity reduction. J Insect Physiol 2010, 56:283-287.

9. Paukku S, Kotiaho JS: Cost of reproduction in Callosobruchus maculatus: effects of mating on male longevity and the effect of male mating status on female longevity. J. Insect Physiol. 2005, 51:1220-6.

10. Bretman A, Westmancoat JD, Gage MJG, Chapman T: Costs and benefits of lifetime exposure to mating rivals in male Drosophila melanogaster. Evolution 2013, 67:2413-22.

11. South SH, Steiner D, Arnqvist G: Male mating costs in a polygynous mosquito with ornaments expressed in both sexes. Proc $R$ Soc B 2009, 276:3671-3678.

12. Wedell N, Gage MJG, Parker GA: Sperm competition, male prudence and spermlimited females. Trends Ecol Evol 2002, 17:313-320.

13. Parker GA: Sperm competition and the evolution of ejaculates: towards a theory 
base. In Sperm competition and sexual selection. . Academic Press; 1998:3-53.

*14. Boivin G: Sperm as a limiting factor in mating success in Hymenoptera parasitoids. Entom Exp App 2013, 146:149-155.

15. Parker GA: Marginal value theorem with exploitation time costs: diet, sperm reserves, and optimal copula duration in dung flies. Am Nat 1992, 139:12371256.

16. Parker GA: Courtship persistence and female-guarding as male time investment strategies. Behav 1974, 48:157-184.

17. Parker G, Simmons L, Stockley P, McCHRISTIE D, Charnov E: Optimal copula duration in yellow dung flies: effects of female size and egg content. Anim. Behav. 1999, 57:795-805.

18. Parker GA, Pizzari T: Sperm competition and ejaculate economics. Biol. Rev. Camb. Philos. Soc. 2010, 85:897-934.

19. Martel V, Wajnberg E, Boivin G: Patch time allocation in male parasitoids. Ecol Entom 2008, 33:608-613.

*20. Dufour CM-S, Louâpre P, van Baaren J, Martel V: When parasitoid males make decisions: information used when foraging for females. PLoS One 2012, 7:e46706.

21. Stephens DW, Krebs JR: Foraging theory. Princeton Univ Pr; 1986.

22. Emlen JM: The role of time and energy in food preference. Am Nat 1966, 100:611-617.

23. Charnov EL: Optimal foraging, the marginal value theorem. Theo Pop Biol 1976, 9:129-136.

24. Bonduriansky R: The evolution of male mate choice in insects: a synthesis of ideas and evidence. Biol Rev 2001, 76:305-339.

25. Simmons LW: Nuptial feeding in tettigoniids male costs and the rates of fecundity increase. Behav Ecol Sociobiol 1990, 27.

26. Briegel H: Metabolic relationship between female body size, reserves, and fecundity of Aedes aegypti. J. Insect Physiol. 1990, 36:165-172.

27. Honěk A: Intraspecific variation in body size and fecundity in insects: a general relationship. Oikos 1993, 66:483-492.

28. Fox C: Multiple mating, lifetime fecundity and female mortality of the bruchid 
beetle, Callosobruchus maculatus (Coleoptera: Bruchidae). Funct. Ecol. 1993, 7:203-208.

29. Fox CW: Oecologia The influence of maternal age and mating frequency on egg size and offspring performance in Callosobruchus maculatus (Coleoptera: Bruchidae). Oecologia 1993, 96:139-146.

30. Martin OY, Hosken DJ: Copulation reduces male but not female longevity in Saltella sphondylli (Diptera: Sepsidae). J Evol Biol 2004, 17:357-362.

31. Dewsbury DA: Ejaculate cost and male choice. Am Nat 1982, 119:601-610.

32. Johansson BG, Jones TM, Widemo F: Cost of pheromone production in a lekking Drosophila. Anim Behav 2005, 69:851-858.

*33. Edward DA: The description of mate choice. Behav. Ecol. 2014, 00:1-10.

34. Parker G: Mate quality and mating decisions. In Mate choice. Edited by Bateson P. 1983:141-164.

35. Katvala M, Kaitala A: Male choice for current female fecundity in a polyandrous egg-carrying bug. Anim Behav 2001, 62:133-137.

36. Vijay Kumar BK, Krishna MS: Evidence of Male Mate Choice for Female Age in Drosophila Nasuta. Am. J. Biosci. 2014, 2:157.

37. Khan I, Prasad NG: Male Drosophila melanogaster show adaptive mating bias in response to female infection status. J. Insect Physiol. 2013, 59:1017-23.

38. Markov AV, Lazebny OE, Goryacheva II, Antipin MI, Kulikov AM: Symbiotic bacteria affect mating choice in Drosophila melanogaster. Anim. Behav. 2009, 77:1011-1017.

39. Liu X-P, He H-M, Xue F-S: The influence of female age on male mating preference and reproductive success in cabbage beetle, Colaphellus bowringi. Insect Sci. 2014, 21:515-22.

*40. Louâpre P, Llopis S, Martel V, van Baaren J: Sperm-depleted males influence the reproductive behaviour of conspecifics. Naturwissenschaften 2014, doi:10.1007/s00114-014-1227-6.

41. Byrne PG, Rice WR: Evidence for adaptive male mate choice in the fruit fly Drosophila melanogaster. Proc. Biol. Sci. 2006, 273:917-22.

*42. Nandy B, Joshi A, Ali ZS, Sen S, Prasad NG: Degree of adaptive male mate choice is positively correlated with female quality variance. Sci. Rep. 2012, 2:447. 
43. Barrette M, Wu G-M, Brodeur J, Giraldeau L-A, Boivin G: Testing competing measures of profitability for mobile resources. Oecologia 2009, 158:757-764.

*44. Martel V, Boivin G: Do choice tests really test choice?. J Insect Behav 2011, 24:329-336.

45. Wigby S, Sirot LK, Linklater JR, Buehner N, Calboli FCF, Bretman A, Wolfner MF, Chapman T: Seminal fluid protein allocation and male reproductive success.

Curr. Biol. 2009, 19:751-7.

46. Thomas ML, Simmons LW: Male crickets adjust the viability of their Sperm in response to female mating status. Am. Nat. 2007, 170:190-195.

47. Wedell N, Cook P: Butterflies tailor their ejaculate in response to sperm competition risk and intensity. Proc. R. Soc. B 1999, 266:1033-1039.

48. Perez-Staples D, Aluja M: Sperm allocation and cost of mating in a tropical tephritid fruit fly. J. Insect Physiol. 2006, 52:839-45.

49. Harari AR, Landolt PJ, O’Brien CW, Brockmann HJ: Prolonged mate guarding and sperm competition in the weevil Diaprepes Abbreviatus (L.). Behav Ecol 2003, 14:89-96.

50. Sirot LK, Brockmann HJ, Lapointe SL: Male postcopulatory reproductive success in the beetle, Diaprepes abbreviatus. Anim Behav 2007, 74:143-152.

51. Godfray HCJ: Parasitoids: behavioral and evolutionary ecology. Princeton University Press; 1994.

52. Turlure $\mathrm{C}$, Van Dyck H: On the consequences of aggressive male mate-locating behaviour and micro-climate for female host plant use in the butterfly Lycaena hippothoe. Behav Ecol Sociobiol 2009, 63:1581-1591.

53. Parker GA, Stuart RA: Animal behavior as a strategy optimizer: evolution of resource assessment strategies and optimal emigration thresholds. Am Nat 1976, 110:1055-1076.

54. Fauvergue $\mathrm{X}$, Hopper KR, Antolin MF: Mate finding via a trail sex pheromone by a parasitoid wasp. PNAS 1995, 92:900-904.

55. Waage JK: Foraging for patchily-distributed hosts by the parasitoid, Nemeritis canescens. J Anim Ecol 1979, 48:353-371.

56. Louâpre P, van Baaren J, Pierre J-S, van Alphen JJM: Information gleaned and former patch quality determine foraging behavior of parasitic wasps. Behav. Ecol. 2011, 22:1064-1069. 
57. Pierre J: Neuroeconomics in parasitoids: computing accurately with a minute brain. Oikos 2011, 120:77-83.

58. Edward D a., Chapman T: The evolution and significance of male mate choice. Trends Ecol. Evol. 2011, 26:647-654.

59. Damiens D, Boivin G: Why do sperm-depleted parasitoid males continue to mate?. Behav Ecol 2006, 17:138-143.

60. Van Alphen JJM, Bernstein C, Driessen G: Information acquisition and time allocation in insect parasitoids. Trends Ecol Evol 2003, 18:81-87.

61. Van Alphen JJM, Bernstein C: Information acquisition, information processing, and patch time allocation in insect parasitoids. In Behavioral ecology of insect parasitoids. From theoretical approaches to field applications. Blackwell Science, Oxford. Edited by Wajnber, Bernstein van A. Blackwell Publishing Ltd; 2008:172192. 
Table 1. Transposition of the main OFT assumptions to males foraging for females.

\begin{tabular}{|c|c|}
\hline Assumptions of the OFT & Transposition to males foraging for females \\
\hline \multicolumn{2}{|c|}{ General assumptions } \\
\hline $\begin{array}{l}\text { The currency consists of maximizing } \\
\text { long-term average rate of energy intake } \\
\text { for the forager. }\end{array}$ & $\begin{array}{l}\text { The male aims at maximizing the number of } \\
\text { females mated per unit of time. }\end{array}$ \\
\hline $\begin{array}{l}\text { Encounters with preys/hosts follow a } \\
\text { sequential Poisson process. }\end{array}$ & $\begin{array}{l}\text { The male encounters females one at a time at a } \\
\text { constant encountering probability. }\end{array}$ \\
\hline $\begin{array}{l}\text { The forager has a complete information } \\
\text { and recognizes each prey type and patch } \\
\text { density. }\end{array}$ & $\begin{array}{l}\text { The male has complete information and } \\
\text { recognizes each female type and patch } \\
\text { density. }\end{array}$ \\
\hline $\begin{array}{l}\text { Searching and handling activities are } \\
\text { exclusives. }\end{array}$ & $\begin{array}{l}\text { Seeking and mating females are exclusive } \\
\text { activities. }\end{array}$ \\
\hline \multicolumn{2}{|c|}{ Assumptions of the prey model } \\
\hline $\begin{array}{l}\text { Different prey types can be found in the } \\
\text { environment and provide different } \\
\text { profitability levels for the forager. }\end{array}$ & $\begin{array}{l}\text { Different female types (i.e. virgin, mated....) } \\
\text { can be found in the environment and provide } \\
\text { different profitability levels for the male. }\end{array}$ \\
\hline $\begin{array}{l}\text { Encounter without attack is not costly in } \\
\text { time and energy. }\end{array}$ & $\begin{array}{l}\text { Encounter with a female without mating is not } \\
\text { costly for the male. }\end{array}$ \\
\hline $\begin{array}{l}\text { The decision of the forager is to attack or } \\
\text { not a given prey upon encounter according } \\
\text { to the rate at which each prey type is } \\
\text { encountered. }\end{array}$ & $\begin{array}{l}\text { The decision of the male is to mate or reject } \\
\text { the encountered females according to the rate } \\
\text { at which each female type is encountered. }\end{array}$ \\
\hline \multicolumn{2}{|c|}{$\begin{array}{ll}\text { Assumptions of the patch model } \\
\end{array}$} \\
\hline $\begin{array}{l}\text { The forager sequentially visits different } \\
\text { patch types of varying quality. }\end{array}$ & $\begin{array}{l}\text { The male visits successively a sequence of } \\
\text { patches formed by a various number of } \\
\text { females or by their quality. }\end{array}$ \\
\hline $\begin{array}{l}\text { The energy gain obtained in a given patch } \\
\text { type is a decelerating function of time due } \\
\text { to patch depletion. }\end{array}$ & $\begin{array}{l}\text { The number of females the male mates in a } \\
\text { patch increases at a decelerating rate due to } \\
\text { mating. }\end{array}$ \\
\hline $\begin{array}{l}\text { The decision of the forager is to stay or } \\
\text { leave the patch at the appropriate time. }\end{array}$ & $\begin{array}{l}\text { The decision of the male is to stay or leave the } \\
\text { patch of females at the appropriate time. }\end{array}$ \\
\hline
\end{tabular}

